\title{
Um teatro pós-moderno de resistência: Oi nóis aqui traveiz de Porto Alegre
}

\author{
Ingrid Koudela
}

Envie-me um escriba ou, melhor ainda, uma jovem escrava com memória afiada e voz possante. Disponha que ela, o que ouvir de mim, possa dizer à sua filha. Esta por sua vez à sua filha, e assim por diante. De forma que, ao lado da torrente de cantos a heróis, este minúsculo arroio, penoso, também possa alcançar aquelas pessoas distantes, talvez mais felizes, que um dia hão de viver (Christa Wolf).

ma educação política que pratique a educação estética e uma educação estética que leve a sério a formação política terão de esforçar-se para alcançar uma consciência capaz de superar a diferença entre a esfera do estético e a do político no seu conceito de cultura. Ou seja: ambas as esferas não podem ser submetidas a um denominador comum, pois tal redução significaria o fim da arte. Por outro lado, não há como separar tais domínios um do outro, posto que se inter-relacionam continuamente, através de um processo de oscilaçôes. O político deve ser constantemente resguardado de modo a não se tornar unidimensional e cabe-lhe trazer ao estético a consciência de que ele se acha sob o signo do como se.

A superação do vácuo hoje tantas vezes existente entre cultura e política é ultrapassada pelo grupo Oi Nóis Aqui Traveiz através da estratégia de resistência. A desestabilização das estruturas de poder se realiza através da prática libertária da criação coletiva praticada pelos atuadores da paixão e de uma necessidade de transformação do próprio teatro praticado na Terreira da Tribo, nome dado ao espaço do grande galpão no bairro dos Navegantes, sede do grupo em Porto Alegre.

Em uma sociedade na qual o próprio teatro se tornou uma indústria e a literatura, sua matéria-prima, permanece a proposta brechtiana de um modelo de educação político-estético e experimentação teatral que procura gerar novos meios de produção. Para transformar a sociedade por meio do teatro, é indispensável modificar as estruturas do teatro, que são um reflexo das estruturas da sociedade. Assim como anuncia Brecht, a apropriação dos meios de produção artísticos é necessária e importante para o processo de emancipação do teatro e do público.

\section{A saga de Canudos}

Tive a oportunidade de ver o espetáculo de rua A Saga de Canudos e o que mais me impressio-

Ingrid Koudela é professora do Departamento de Artes Cênicas e do Programa de Pós-Graduação em Artes Cências da ECA-USP. 
nou naquela apresentação realizada em praça pública, no centro de Porto Alegre, foi o primor na representação dos personagens e cenas populares. Formas de manifestação altamente sofisticadas, que incorporam a música e a dança, vemos tantas vezes a autentica cultura brasileira ser vilipendiada por um sucateamento do popular, através de processos de banalização.

O cenário da praça pública exige um gesto ampliado, capaz de prender a atenção de cidadãos que acorrem casualmente, formando a roda da brincadeira teatral. Através de grandes bonecos, figurinos coloridos, tambores e da representação e do canto coral, o grupo Ói Nóis Aqui Traveiz realiza um ato artístico da maior grandeza, do qual participa uma platéia formada por meninos de rua, passantes, donas de casa, comerciantes, turistas.

A qualidade estética desse teatro de rua não degrada o seu cunho político através da afirmação do já existente. Recuperando a qualidade emancipatória e alternativa da arte, o espetáculo A Saga de Canudos permite ao espectador proceder a uma atitude crítica frente à sua história. Ao desenvolver universos de oposição, dialética inerente à adaptação realizada do texto de César Vieira que foi tomado como base para a criação coletiva, o grupo de atuadores radicaliza o conceito de criação coletiva, assumindo o ator como criador intérprete e a encenação como ato praticado através da relação democrática.

A história deste teatro de grupo vem do teatro de rua, da escola da representação popular. Seu discurso político está em processo, tal qual o tempo de transformação da história, diferente neste início de século XXI do primeiro momento, em pleno regime militar (19641985). O que permanece presente é a denúncia na celebração do ato, do teatro de todos os tempos, que não comporta um mundo de vencedores e vencidos porque todos derrotados.

\section{Kassandra in process}

Confrontando-se com o grande objetivo de procurar na história do Ocidente aqueles fragmentos ainda aptos a manter vivo o contraditório processo de oscilações entre o estético e o político, os atuadores celebram Kassandra in Process, com estréia na Terreira da Tribo em 2002.

Christa Wolf publica a narrativa Cassandra (Wolf, 1983) focalizando o mito da profetiza filha do rei Priamo e irmã de Paris, o causador da guerra de Tróia por ter seqüestrado Helena, esposa do rei grego Menelau. Cassandra vaticina a tomada de Tróia, mas não é ouvida pelos seus. Entregue a Agamêmnon como presa de guerra, também prevê a morte de ambos a mando de Clitemnestra, esposa daquele.

Herdeira de Brecht, Christa Wolf introduz o leitor tanto na ação como no processo do narrar, incentivando-o à co-produção do sentido do texto. A poética de Cassandra atesta vários pré-textos, sendo os principais a Ilíada e a Odisséia, de Homero, a tragédia Agamêmnon, de Ésquilo, a Mitologia Grega, de Robert RankeGraves, e o volume Pressupostos de uma Narrativa-Cassandra (Wolf, 1982), resultado de quatro preleçōes que proferiu na Universidade de Frankfurt e publicou junto com a narrativa. Esses ensaios testemunham o processo criador da autora, seu diálogo com a antiguidade clássica e com a escrita feminina. Wolf cita Virgina Woolf e Hélène Cixous.

$\mathrm{O}$ personagem principal da narrativa, Cassandra, pronuncia um monólogo na primeira pessoa em que expõe a sua trajetória como filha de rei e sacerdotisa, os anos de cerco e a tomada de Tróia, recordando sua caminhada interior neste percurso. À medida que a figura de Cassandra é situada historicamente desvenda-se a submissão da mulher na sociedade patriarcal. A narrativa situa-se na passagem do matriarcado para o patriarcado. Como se trata de uma época de transição, ambos os sistemas convivem, podendo ser encontrados vestígios da sociedade matriarcal na comunidade que fica no Monte Ida, onde a violência não tem lugar e as 
relações humanas se baseiam em solidariedade e amizade. Vive-se aí ainda em comunhão com o sensível e a natureza.

A Cassandra de Christa Wolf também não recebe do deus Apolo o dom da visão. Ela mesma conquista essa capacidade, no exercício de seus sentidos e de sua inteligência. Ela converte seu destino em sujeito da história. O curto espaço de tempo na tragédia de Ésquilo é rompido em Cassandra pelo tempo narrado subjetivamente dilatado. O procedimento intertextual da narrativa produz o ecoar de várias vozes. Christa Wolf defende a multiplicidade de referencias. Permanecem assim trechos em aberto na narrativa que apelam para a construção de sentido do leitor.

Kassandra in Process, Aos que virão depois de Nós afirma um teatro que é antes de tudo ritual e mágico, ligado a forças cuja eficácia se traduz em gestos e está ligado diretamente aos ritos que são o próprio exercício e a expressão de uma necessidade espiritual, de acordo com Artaud.

O espetáculo trabalha com o mistério da evocação de um tempo remoto, tão reverenciado pelo teatro. A evocação da mitologia grega, transformada em ritual artaudiano, torna presente no aqui/agora da ação cênica o poder autodestrutivo da humanidade, através da guerra de Tróia, paradigmática do imaginário das guerras no Ocidente, escancarando a atualidade do tema.

A novela de Christa Wolf foi recortada e comprimida, reinstalando o processo criativo de Christa Wolf que convida o leitor a participar como co-produtor de sentidos na leitura de sua narrativa. $\mathrm{O}$ exercício da intertextualidade é continuado e expandido através de autores como Albert Camus, George Orwell, Beckett, Heiner Muller, Peter Handke, Arthur Rimbaud e Pablo Neruda. O processo de criação coletivo aponta para uma prática estética na qual o receptor/leitor/atuador passa a ser ator criador/ autor do texto espetacular.

Esse diálogo na forma de fragmentos irrompe o fio do tempo e rasga o véu da contemporaneidade. Nas palavras de Kassandra: “(...) então, eu me detenho na palavra e, mais ainda do que na palavra, na sua figura, na sua linda imagem. Sempre me afeiçoei mais à imagem do que às palavras. E tudo acabarácom uma imagem, não com uma palavra (...)" (Santos, 2004, p. 51).

O espetáculo conquista a ruptura através da linguagem do espaço e do corpo ritualizados no qual os atuadores são intérpretes que se reduzem à sua menor grandeza, na expressão cunhada por Brecht. O corpo franzino de Tânia Farias que lidera o elenco, torna Kassandra uma gigante em cena. Em outros momentos sua doçura aponta para o que é pequeno e frágil e ainda, em outros faz, o espectador rir... talvez de si próprio ou da crueldade do que lhe é apresentada. O rigor, a radicalidade do grupo dos atuadores comove pela generosidade de sua entrega total à arte teatral.

Kassandra é uma voz vencida e assassinada, reescrevendo a sua história - que é a história da mulher - tentando assegurar a sua transmissão a gerações futuras. A forma do teatro processional faz com que o espectador se veja ora na própria arena dos fatos, ora os veja do alto, com distanciamento. A platéia é tocada pela proximidade física do atuador, envolvido em oferendas, banquetes, combates, despedidas, assassinatos, jogos de sedução e poder. $\mathrm{Na}$ seqüência de um genocídio, há homenzinhos do tamanho da palma da mão, trapinhos de pano azul espalhados pelo chão. A platéia se torna cúmplice da contagem dos mortos, andando com cuidado redobrado para não esmagá-los.

Um silêncio perturbador invade os espectadores ao término da apresentação. Não há aplausos. Ouve-se apenas o caminhar das pessoas saindo da Terreira da Tribo. No SESC Pompéia, ao final do espetáculo, em São Paulo, o fotógrafo puxou palmas e a platéia até obedeceu, acompanhando. Mas elas cessaram rapidamente e, na saída, o mesmo desassossego, olhos buscando a noite e a sensação do vento no rosto. Kassandra in Process, três horas memoráveis de teatro depois das quais o espectador já não é mais o mesmo... algo dentro dele faz com que o fôlego se altere...o aplauso já não mais se instaura na sua forma convencional. 


\section{A missão de Heiner Müller}

No cruzamento de tantos carinhos e tantos outros caminhos ásperos trago a trajetória da atriz Marta Haas que faz o personagem de Primeiro Amor em A Missão (Müller, 1979) na encenação de Ói Nóis Aqui Traveiz.

À noite, aos finais de semana, Marta Haas se apresenta na Terreira da Tribo, fazendo “(...) aquilo que fazem as crianças com as bonecas. De vez em quando a criança quer saber o que há dentro da boneca. Para isso, é necessário quebrá-la, senão não saberá jamais o que há no interior" (Müller, 1986, p. 125).

A menina de longos cabelos loiros, do interior do Estado do Rio Grande do Sul está inserida em um processo de pesquisa mülleriano cuja moral é uma pulsão antropológica - querer saber o que há dentro da boneca.

De dia, durante a semana, a atriz Marta Haas ministra oficinas para iniciantes em bairros periféricos de Porto Alegre. A Escola de Teatro Popular da Terreira da Tribo fomenta a pesquisa de processos atorais e oferece oficinas abertas à comunidade em geral propondo uma abordagem que privilegia a idéia de um teatro político. Pedra angular do projeto pedagógico do Centro de Experimentação e Pesquisa Cênica é a prática artística como elemento transformador.

$\mathrm{O}$ grande abismo que havia entre a alta literatura e a proposta pedagógica é superado sujeito e objeto tornam-se finalmente idênticos "(...) trata-se aqui da realidade humana e não de uma natureza independente de sua consciência, ela deve ser transformada" (Muller, 1986, p. 66). O teatro de Heiner Müller insiste na sua qualidade de tradução para outra unidade de tempo e espaço.

Da mesma forma como a atriz Marta Haas, gente de teatro por todo o Brasil enfrenta o confronto com o branco no olho da História. Nesse peito a peito com a realidade social, seu teatro renasce muitas vezes após passar por um processo de transmutação.

A Missão insere-se na produção literária e teatral contemporânea como documento de um tempo em crise, em que tudo espera por história. É nesse contexto de um estado em suspenso que Muller situa o Terceiro Mundo com todos os problemas de fome e superpopulação. De um lado, objeto de colonização, exploração e refugo, de outro, lugar de caos e desordem, o Terceiro Mundo é visto por ele como fermento do novo: “(...) ilhas de desordem, espécie de tumores benignos na medida em que, forçando o convívio com camadas diversificadas de história e cultura, preparam o solo para a mudança" (Müller, 1986, p. 87).

Ministrante da disciplina Teoria e Prática da Peça Didática de Bertolt Brecht no Curso de Pós-Graduação da ECA-USP, sou necessariamente confrontada com esta pós-modernidade de resistência.

Em 2005 encenamos com os alunos do curso de pós-graduação Sangue na Sapatilha de Heiner Müller (Müller apud Koudela, 2003, p. 59), escrito em homenagem a Pina Bausch, como performance, apresentada no Paço das Artes da USP e no Teatro Laboratório da ECA.

A experiência de trabalhar com um texto de Müller transforma não apenas o conceito de teatro como gera uma profunda agitação e transformação da prática teatral. A minha mais viva sensação foi aquela descrita pelo autor quando cita o Fragmento Fatzer de Brecht, como um processo de autoconhecimento. $\mathrm{Na}$ versão de Müller intitulada Declínio do Egoista Johann Fatzer, escreve na introdução:

"No primeiro caderno dos Versuche há um texto do Fragmento Fatzer. Li esse texto nos anos cinqüenta e desde então o Fatzer é para mim um objeto de inveja. Trata-se de um texto secular, pela qualidade literária e pela condensação. Seu tema tem a ver com as grandes cidades (...) há por volta de quatrocentas páginas no Arquivo Bertolt Brecht, material difuso, às vezes há uma linha em uma página, às vezes uma página inteira, esboços de diferentes versões.

No quarto em que estava trabalhando, esparramei as quatrocentas páginas e 
andava em meio a elas, procurando o que combinava.

Também estabeleci relações nas quais Brecht não poderia ter pensado, um quebracabeças" (Brecht/Müller, 2002, p. 11).

Para Müller, no texto do Fatzer, a língua escande o processo do pensamento cuja atitude é aquela do pesquisador científico. Brecht faz o comentário do fragmento "(...) como antigamente fantasmas vinham do passado, assim também agora (vêm) do futuro”. E Müller declara: “(...) os fantasmas não ameaçam apenas surgir do passado, mas como motoristas loucos na via expressa do futuro" (Müller, 1986, p. 55).

Ao chegar em casa depois das aulas, meus papéis estavam como que em revolta, resistentes a uma organização linear. Textos de Caetano Veloso, ritmos indígenas e imagens dos espetáculos de Pina Bausch compunham o nosso texto espetacular informado pelo exercício intertextual. A revolta dos papéis é também uma revolução nos conceitos acadêmicos tradicionais contra os quais este teatro da pós-modernidade se rebela... nascendo a partir daí várias questôes. O texto mülleriano, no qual intertextualidade e desconstrução constituem-se como método de pesquisa permitia à ação de alunos e professora encenadora uma grande liberdade, abrindo caminho para a antropofagia, conforme conceitua Ruth Röhl, com grande propriedade em sua pesquisa sobre a literatura na República Democrática Alemã (Röhl, 2006).

O diálogo publicado com o título $O$ Espanto como primeira aparição do novo (Müller apud Koudela, 2003) coloca um princípio estético que permite o paralelo com a antropofagia - a transformação permanente do tabu em totem. A idéia de Oswald de Andrade, de que o tabu deve ser transformado em totem, subverte por completo a reflexão de Freud, por colocar justamente o proibido, o indesejável como algo digno do desejo. Transformando o oposto à norma em objeto de busca, Andrade instaura a ruptura como procedimento ideal, procedimento esse que subjaz às palavras de Müller quando afirma que o novo é geralmente um fator de perturbação da ordem. Apesar das diferenças entre os dois dramaturgos, procedimentos comuns como à deglutição intelectual, a representação parodia, a irreverência e a provocação são justificáveis pela tradição - no caso de Andrade a Semana de Arte Moderna, no de Muller o conhecimento e incorporação das vanguardas européias (Maiakovski, Duchamp, Kafka etc.).

Já encontramos em Hegel que a forma é um reservatório de conteúdo e as formas antigas deixam transpirar as velhas ideologias. $\mathrm{Na}$ dicção de Brecht, "conteúdos novos em panelas velhas", ou seja, em teatro não basta dizer coisas novas. É preciso, também dizê-las de outras formas. Para Brecht ser contemporâneo na escrita e na encenação não é contentar-se em registrar as mudanças na sociedade, é também intervir na conversão das formas. A Brecht não interessa uma determinada forma de encenar, mas a configuração de um leque de opçōes, isto é, a apropriação critica, por parte do grupo, do maior número possível de ferramentas de criação e leitura.

$\mathrm{Na}$ contemporaneidade, o espectador já não se contenta em reconhecer um estilo e reter uma história. Ele participa também da montagem. O modelo de encenação pós-moderno se caracteriza por uma escritura narrativa que não mais se apóia no contar ou apresentar uma estória para o público, mas sim conexões em rede de fabulação nas qual o fragmento, a colagem, a simultaneidade se constituem como instrumento de exposição cênico.

Esta forma de encenação é sugerida através de modelos artísticos como Wilson, Kantor, Bausch, Thomas, Lepage, Fúria del Baús. De acordo com Muller, “(...) o teatro de Robert Wilson, tão ingênuo como elitizado, dança mordaz infantil e brincadeira de criança matemática, não faz diferença entre leigos e atores. Perspectiva de um teatro épico, como Brecht o concebeu e não realizou, com um mínimo de esforço dramatúrgico e além da perversidade de transformar um luxo em profissão. Os quadros de parede das minorias e a arte proletária do subway, 
anônima e feita com tinta roubada, ocupam um campo para além do mercado. Antecipação da miséria dos subprivilegiados é o Reino da Liberdade, que fica além dos privilegiados. Paródia da projeção de Marx da superação da arte numa sociedade cujos participantes são também artistas” (Müller, apud Koudela, 2003, p. 47).

Müller produziu o quarto ato da peça The CIVIL Wars de Robert Wilson (1984), mostrando-se entusiasmado com o que chama de Theater als Prozess ("teatro como processo"), no qual a tensão dramática criada entre palco e platéia é explicitada, em oposição ao que chama Theater als Zustand ("teatro de situação"), aquele que conserva uma estrutura historicamente anacrônica e mantém a dicotomia entre palco e platéia, sendo que os espectadores assumem uma postura meramente contemplativa.

$\mathrm{O}$ que entusiasmou Müller em Robert Wilson foi a liberdade entre os elementos que compõem a cena, não interpretando, como diretor, nem permitindo que os atores o façam. A interpretação, na opinião de Muller, é tarefa única e exclusiva do público-receptor. Ela não deve ter lugar no palco.

Descrição de Imagem (Müller, 1984), por exemplo, oferece extrema resistência ao sentido devido à inflação do material. Antes que uma imagem se complete já surge a seguinte e assim por diante, de forma que o espectador fica sem o arremate, sem a moldura que poderia facilitar sua leitura. É essa maior dificuldade que vai liberar a sua fantasia. Descrição de Imagem é uma reflexão sobre o theatron, o espaço do público receptor, ao pé da letra espaço de contemplação: o texto não apresenta diálogo nem ação, mas um encontro dramático entre olhar e imagem.

O espaço do corpo no teatro é testemunhado por Muller através de sua reverencia a Artaud: “(...) sério é o caso de Artaud. Ele desapropriou a literatura da polícia, o teatro da medicina. Sob o sol da tortura, que ilumina simultaneamente todos os continentes deste planeta, seus textos florescem. Lidos a partir das ruínas da Europa, serão clássicos" (Müller apud Koudela, 2003, p. 57).
A redução do diálogo dramático em favor do jogo de fragmentos, pela montagem de tempos, gêneros, níveis estilísticos e formas de representação heterogênea, fornece a uma peça como A Missão a feição de uma constelação pósmoderna. De acordo com Röhl: "a base da representação pós-moderna é o modelo bakhtiniano do dialógico, não dialética resolvida. Respeitante ao público-receptor, a polissemia é também uma motivação ao prazer, à fruição da representação artística, que nunca ocorre numa recepção puramente passiva, mas quando depara com signos opacos, resistentes ao sentido" (Röhl, 1997, p. 168).

$\mathrm{Na}$ Terreira da Tribo as imagens surrealistas, aparentemente caóticas da escritura de Müller, compostas por passagens clownescas, citações, teatro de marionetes, fantasmagorias, teatro ritual artaudiano geram uma invasão de quadros e metáforas que desafiam a energia e leva ao extremo as possibilidades de recepção da platéia, composta de no máximo vinte e cinco espectadores.

Os atuadores produzem um espetáculo no qual o fragmento sintético é montado como um quebra-cabeça espacial através do qual somos conduzidos por uma sucessão de instalações (composições de cenários e figurinos). Nesse procedimento processional da montagem, $\mathrm{o}$ espectador é conduzido através de diferentes ambientes que provocam experiências sensoriais através de temperaturas, cheiros, espaços pequenos e confinados e céu aberto, grandes salas, diferentes planos como alto e baixo, texturas como areia e água, luzes de velas, escuridôes, sons de tambores musica clássica e ritual vodu.

Também o figurino se aproxima desse caráter de instalação através de dimensões gigantescas das roupas na caracterização de Primeiro Amor, em que ouvimos o texto: “isto é o homem: seu primeiro lar é sua mãe, uma prisão. Aqui está aberta a pátria, aqui boceja o seio da família. Diga uma única palavra, se você quer voltar e ela te enfia para dentro, a idiota, a mãe eterna". Debuisson literalmente entra para a barriga de Primeiro Amor, a instalação (figu- 
rino/cenário) da imensa saia tem a forma de uma alcova, na metáfora da supressão da liberdade ligada ao nascimento com a analogia entre mãe e pátria e a solidão do dissidente político Debuisson.

Nas encenações no espaço da Terreira da Tribo o espaço teatral é modificado por completo, de modo que a disposição da platéia se dá em função da criação de cada cena. A palavra poética de Muller é articulada na montagem com a poesia do espaço transfigurando a qualidade da palavra como presença física, corporificada através da instalação.

Os atuadores Paulo Flores, Sandro Marques, Tânia Farias, Clelio Cardoso, Marta Haas,
Renan Leandro, Pedro Kinast de Camillis, Carla Moura, Luana Fernandes são atores pesquisadores que participam do processo de construção da forma estética assumindo o princípio da criação coletiva, do teatro que nasce do ator dentro de um processo de criação radicalmente democrático, no qual a função do diretor/encenador é abolida. A interpretação deste grupo se caracteriza por uma atuação em estado alterado, um relativo abandono em função do caráter ritualístico artaudiano de seu teatro. $\mathrm{O}$ transbordamento da ação em direção à platéia faz nascerem signos que precipitam sonhos/pesadelos, cuja qualidade estética arrebata o espectador e provoca o desassossego.

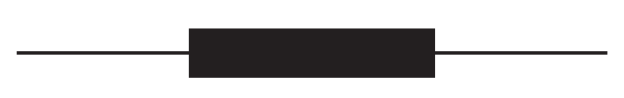

\section{Referências bibliográficas}

BRECHT, Bertolt. Fatzer. Berliner Ensemble. Staatstheater der Deutschen Demokratischen Republik. Leitung, Manfred Wekwerth. Redaktion, Werner Mittenzwei. In: Brecht Jahrbuch, 1980. . Fatzer. In: BRECHT, Bertolt. Grosse Kommentierte Berliner und Frankfurter Ausgabe. Bd. 10 Stückfragmente, Berlin/Weimar/Frankfurt: Aufbauverlag/Suhrkampverlag, 1996.

BRECHT, Bertolt \& MÜLLER, Heiner (Orgs.). O declinio do egoista Johann Fatzer. Tradução de Cristine Röhrig. São Paulo: Cosac \& Naify, 2002.

KOUDELA, Ingrid Dormien. Brecht na pós-modernidade. São Paulo: Perspectiva, 2001. . Brecht: um jogo de aprendizagem. São Paulo: Perspectiva, 1991. . Um vôo brechtiano. São Paulo: Perspectiva, 1992. . Texto e jogo. São Paulo: Perspectiva, 1996.

MÜLLER, Heiner. Medeamaterial e outros textos. Tradução de Fernando Peixoto. São Paulo: Paz \& Terra, 1993.

. Gesammelte Irrtümer. Interviews und Gespräche. Frankfurt: Verlag der Autoren, 1986.

MÜLLER, Heiner \& KOUDELA, Ingrid Dormien (Orgs.). O Espanto no Teatro. Tradução e organização de Ingrid Koudela. São Paulo: Perspectiva, 2003. 
RÖHL, Ruth. O Teatro de Heiner Muller. Modernidade e Pós-Modernidade. São Paulo: Perspectiva, 1997.

. A Literatura na República Democrática Alemã. São Paulo: Perspectiva, 2006.

SANTOS, Valmir. Ói Nois na Memória. Aos Que virão depois de nós. Kassandra in Process. O Desassombro da Utopia. PA: Terreira da Tribo 2004.

WOLF, Christa. Voraussetzungen einer Erzählung: Kassandra. Frankfurter Poetik Vorlesungen. München: DTV, 1993.

Kassandra. Erzählung. Dramstadt/Neuwied: Luchterhand Verlag, 1983. 